\title{
Deforestation detection in the Amazon with an AVHRR-based system
}

\author{
A. C. DI MAIO MANTOVANI \\ Universidade do Vale do Paraiba/UNIVAP_C. Postal 82-12201, \\ São José dos Campos, SP-Brazil \\ and A. W. SETZER \\ Instituto Nacional de Pesquisas Espaciais/INPE-C. Postal 515-12201, \\ São José dos Campos, SP-Brazil
}

(Received 20 July 1995; in final form 25 May 1996)

\begin{abstract}
This paper presents initial tests of a novel and relatively simple methodology for near real-time operational detection of deforestation in Amazonia. Channel $3(3 \cdot 7 \mu \mathrm{m})$ full resolution $(1 \cdot 1 \mathrm{~km})$ and geometrically corrected images of the Advanced Very High Resolution Radiometer (AVHRR) on-board the NOAAseries satellites covering the same region on different dates are digitally compared. Differences in forest cover between pairs of images are automatically selected as potential deforestation sites. In the tests, three AVHRR images (September 1989 and 1990; July 1990) were compared with $30 \mathrm{~m}$ high-resolution Landsat Thematic Mapper (TM) data using a geographical information system (GIS) integrated to the image processing. The percentages of correct location of newly deforested sites for September 1989-1990 and September 1990-July 1990 comparisons were, respectively: $49 \cdot 1$ and $56 \cdot 5$ per cent for about 200 deforestation sites of assorted sizes, and 82 and 90 per cent for sites larger than $3 \cdot 1 \mathrm{~km}^{2}$.
\end{abstract}

\section{Introduction}

South America's tropical forest ecosystems have been sized at about $7 \cdot 6 \times 10^{6} \mathrm{~km}^{2}$ (Martini 1993) and primary forests still cover a significant part of this area. Changes in tropical vegetation are a major concern in studies of regional and global biogeochemical cycles and climate, and in biodiversity losses. Estimates of the Amazon forest losses have been made using $30 \mathrm{~m}$ high resolution Thematic Mapper (TM) images of the Landsat satellites. In the case of Brazil, which contains around $4 \times 10^{6} \mathrm{~km}^{2}$ of the Amazon forest (Fearnside 1990), estimates based on the visual analysis of 1:250 000 scale photographic colour composite images of three TM channels yielded an average loss of $21130 \mathrm{~km}^{2}$ year $^{-1}$ for the period 1978-1989; total Brazilian deforestation was calculated as $426400 \mathrm{~km}^{2}$ until 1991 (INPE 1992). Skole and Tucker (1993), also considered forest fragmentation caused by deforestation, and estimated in 1:500 000 black-and-white single-channel TM photograph images that about $590000 \mathrm{~km}^{2}$ of the forest were altered from a biological diversity point of view until 1988. Although these studies lacked systematic field work validation, both consumed years of continuous work with associated costs of the order of $10^{6}$ U.S. Dollars.

The Advanced Very High Resolution Radiometer (AVHRR) on board the NOAAseries satellites, despite its low resolution of $1.1 \mathrm{~km}$ at nadir, has also been used in numerous forest studies (e.g., Justice et al. 1985, Malingreau and Tucker 1988, and Cross 1991). Among the advantages of its images are the daily coverage of continental-size areas and very low image acquisition and processing costs. This high imaging frequency results in cloud-free images in the dry season for most tropical 
areas (Malingreau and Tucker 1988). Processing that combines large digital databases of orbital images and geocoded information is most efficiently performed through geographical information systems, GISs (Ehlers et al. 1989), and can therefore improve the adequate monitoring of natural resources across large regions.

The main objective of this work was to test a methodology developed for lowcost operational semi-automatic detection of major changes in the vegetation cover of the Amazon forest, based on the integration of AVHRR/NOAA imagery with a high resolution database in a GIS. Such a methodology, if successfully applied on a wider scale, could be used to monitor the Amazon vegetation on a continuous nearreal time basis, providing information needed and not yet available.

\section{Methodology}

A summary of the materials used and the methodology developed is presented in this session. A more complete description may be found in the internal report prepared by Di Maio Mantovani (1994).

\subsection{Study area}

The study area is located in the Brazilian Legal Amazon region, in the state of Mato Grosso, and is indicated in figure 1. The five sub-areas shown in the same figure were used in the tests of the methodology, and correspond to the 1:250000 scale topographic chart division of Brazil (IBGE 1982, DSG 1981-3). Prevailing forest types in this region are rain/ombrophilous, open, seasonal, semi-decidual, and dense closed savannas, with natural ecological strains common among them. Smoke palls in the region are common in the dry season as a result of intense biomass burning use to prepare and clean pastures or in the conversion of fallen tracts of forest. Spatial patterns of deforestation are normally associated with medium to
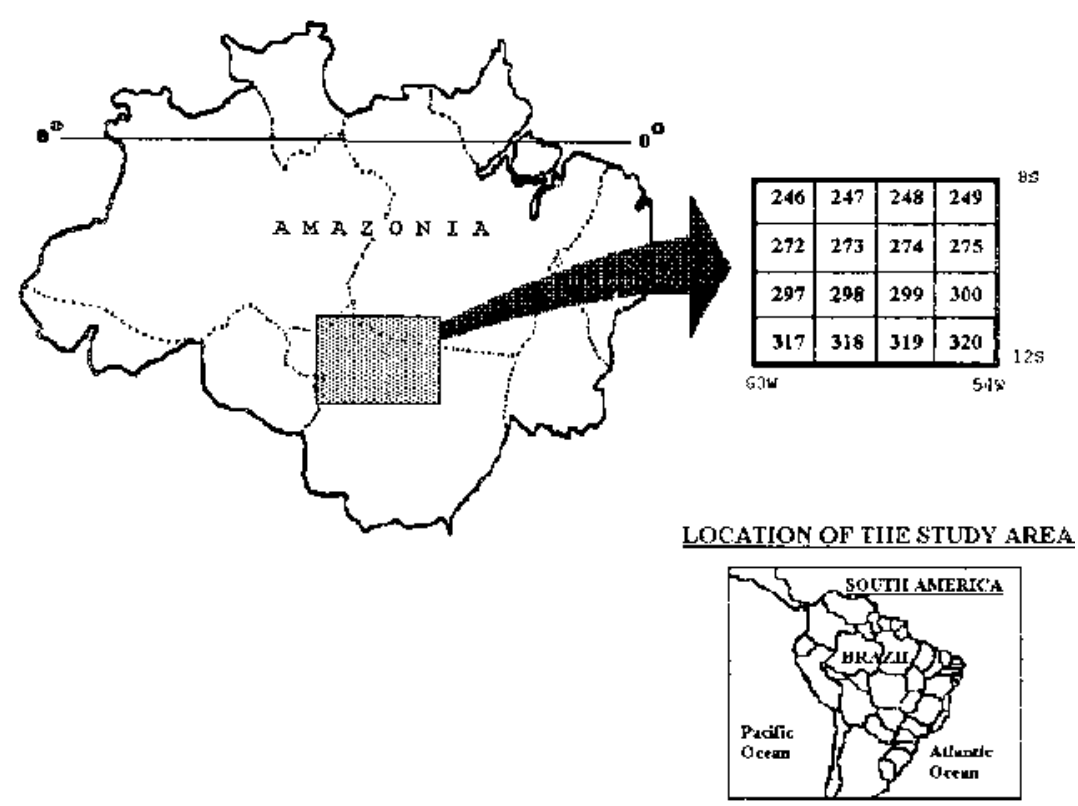

Figure 1. Location of the study areas referenced to the MIR codes 274, 297, 298, 319 and 320. 
large ranching and farming (Projeto RADAM-Brasil 1980) but fish-bone patterns in the midst of small properties also exist.

\subsection{NOAA/AVHRR images}

The images from the Advanced Very High Resolution Radiometer (AVHRR) on-board the NOAA-11 satellite (Kidwell 1993) used are listed in table 1 and were received by the Brazilian National Space Institute (INPE) facilities at C. Paulista, $\mathrm{SP}$, in the maximum spatial $(1 \cdot 1 \mathrm{~km})$ and radiometric (10-bit) resolutions of the High Resolution Picture Transmission (HRPT) mode. Based on the previous pioneering work of Amaral (1992 a and b) we used just channel 3 images $(3 \cdot 5-3 \cdot 7 \mu \mathrm{m})$ to detect new deforestation in this investigation. According to these references, a comparison of TM and AVHRR data for large deforestation sites in Amazonia showed that just the use of AVHRR channel 3 images produced better results in comparison to other AVHRR channels or channel combinations. For instance, the average digital counts ( \pm variance) for forest and deforestation in channel 3, using a scale of 256 levels, were $127 \pm 6.7$ and $53 \pm 44.9$, while in the vegetation index combination of channels 1 and 2 the counts were $162 \pm 4.6$ and $126 \pm 135 \cdot 8$, respectively (Amaral $1992 \mathrm{~b}$ ). Also, the linear regression of $R^{2}=0.93$ found for area estimates between AVHRR channel 3 and TM data was far superior to any other results presented in previous AVHRR work. Subsequently, Kaufman and Remer (1994) reported on the use of AVHRR channel 3 in vegetation studies in the U.S.A., and analysed its physical interaction with the atmosphere; among their conclusions, the reflectance in channel 3 was shown to be more sensitive than the reflectance at $0.64 \mu \mathrm{m}$ and NDVI to the presence of forest and separates it better from open field regions. They also suggest a main limitation of channel 3, the need to correct for the surface emissivity (Kaufman and Remer 1994). How AVHRR channel 3, which integrates emittance and reflectance in its readings, presents such positive results in the detection of forest boundaries, is still an open question.

The images were processed in a SITIM-340 (INPE, 1986) using 8-bit resolution. The SIG-INPE geographical information system (INPE 1989) was used to crosscompare the images for temporal analysis. In order to overlap AVHRR images of different dates, they were initially corrected for geometric distortion caused by the ever-changing viewing geometry of AVHRR; the INPE software of Fernandes et al. (1993) was used. The programme generates $1 \cdot 1 \mathrm{~km}$ resolution images in the cylindrical equidistant projection as final products.

Digital comparison of the study area images also required radiometric compensation of the AVHRR images due to differences in solar illumination, in the Sun-targetsensor geometry between images and in surface temperature. Such effects are observable in the means and standard deviations of grey-level counts (DNs) which change

Table 1. NOAA/AVHRR images used in the study.

\begin{tabular}{lcc}
\hline & \multicolumn{2}{c}{ AVHRR equatorial crossing } \\
\cline { 2 - 3 } Acquisition date & Hour (UTC) & Longitude (W) \\
\hline 17 September 1989 & $17: 40: 04$ & $57^{\circ} 13^{\prime} 48^{\prime \prime}$ \\
30 July 1990 & $18: 10: 53$ & $60^{\circ} 42^{\prime} 36^{\prime \prime}$ \\
15 September 1990 & $17: 59: 16$ & $56^{\circ} 51^{\prime} 00^{\prime \prime}$ \\
\hline
\end{tabular}


significantly for same areas in different AVHRR images, even if only one day apart, and particularly for channel 3. This compensation was based on the selection of a specific cut-off grey level threshold in each image to discriminate forest from non-forest.

\subsection{Landsat-5/T $M$ images and derived maps}

Also used were 1:250 000 classification maps of the INPE Amazonia Information System, AIS (Alves et al. 1992). The maps were generated from visual analysis of Thematic Mapper (TM) imagery of the Landsat-5 satellite. The TM source images were also received by INPE at full radiometric and spatial resolution. This imagery is available in photographic colour prints combining the TM channels $3(\sim 0.65 \mu \mathrm{m})$, $4(\sim 0.85 \mu \mathrm{m})$ and $5(\sim 1.6 \mu \mathrm{m})$; they were used by the AIS to generate a set of 332 maps to evaluate yearly deforestation increases. The five thematic charts used correspond to the same five sub-areas of figure 1 and coincide with the standard mapping reference MIR shown in table 2. This table also indicates the TM images used to verify the AVHRR detection technique.

\subsection{Data integration}

The AVHRR channel 3 images of different dates, after geometric correction to the cylindrical equidistant projection, were compared on an individual pixel basis in the GIS to produce a difference image. The resulting images contained indications of potential sites with vegetation changes; for each of these sites the GIS provided geographical coordinates.

\section{Results and discussion}

\subsection{Accuracy of imagery navigation}

The accuracy of the geographical location of pixels in AVHRR full resolution images is a critical point in the overlay of different images in a digital crosscomparison. An estimate of this accuracy for the images used in this work is presented in table 3, where map coordinates for ten known landmarks were compared with

Table 2. Landsat TM images used in the thematic charts.

\begin{tabular}{|c|c|c|}
\hline MIR charts & $\begin{array}{l}\text { TM images } \\
\text { path/lane }\end{array}$ & TM acquisition dates \\
\hline & $227 / 66$ & 21 July 1989-24 July 1990 \\
\hline & $227 / 67$ & 21 July 1989-26 September 1990 \\
\hline \multirow[t]{4}{*}{274} & $228 / 66$ & 14 September $1989-1$ September 1990 \\
\hline & $228 / 67$ & 26 June 1989-1 September 1990 \\
\hline & $229 / 67$ & 20 August 1989-7 August 1990 \\
\hline & $229 / 68$ & 5 September 1989-7 August 1990 \\
\hline \multirow[t]{4}{*}{297} & $230 / 67$ & 12 September 1989-30 August 1990 \\
\hline & $230 / 68$ & 12 September $1989-30$ August 1990 \\
\hline & $228 / 67$ & 26 June 1989-1 September 1990 \\
\hline & $228 / 68$ & 28 July 1989-1 September 1990 \\
\hline \multirow[t]{3}{*}{298} & $229 / 67$ & 20 August $1989-7$ August 1990 \\
\hline & $229 / 68$ & 5 September 1989-7 August 1990 \\
\hline & $226 / 68$ & 14 July 1989-2 August 1990 \\
\hline \multirow[t]{3}{*}{319} & $227 / 68$ & 21 July 1989-26 September 1990 \\
\hline & $228 / 68$ & 28 July $1989-1$ September 1990 \\
\hline & $225 / 68$ & 8 August 1989-28 September 1990 \\
\hline 320 & $226 / 68$ & - $\quad 2$ August 1990 \\
\hline
\end{tabular}




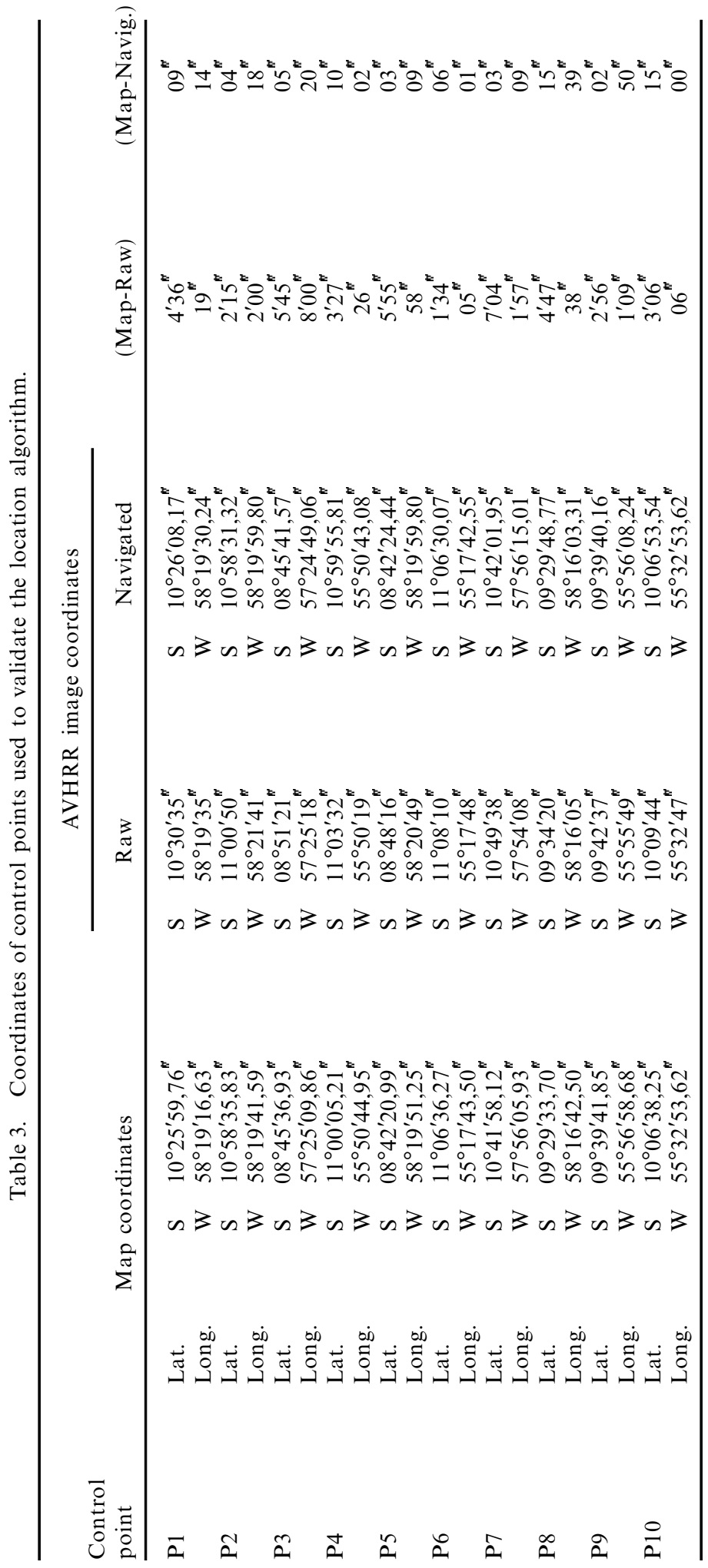


the navigated values obtained for these references in the AVHRR raw and geometrically corrected images. The average difference between coordinates in the map and in the raw images was $4^{\prime} 08^{m}$ in latitude and $47^{m}$ in longitude; in relation to the corrected image the differences were $07^{\prime \prime}$ and $16^{\prime \prime}$, respectively. Assuming that one degree of latitude or longitude corresponds to $111 \mathrm{~km}$ at the equator, one minute becomes $1.9 \mathrm{~km}$ and one second $31 \mathrm{~m}$. Thus the average accuracy of the navigation in the geometrically corrected image was $215 \mathrm{~m}$ in latitude and $493 \mathrm{~m}$ in longitude, and therefore less than a pixel at nadir $(1 \cdot 1 \mathrm{~km})$. Figure 2 shows the AVHRR channel 3 images used in this work in their geometric corrected form for each of the dates analysed. Darker tones correspond to higher temperatures/reflectances, which represent deforested areas, while white pixels indicate clouds.

\subsection{Image radiometric bias}

Significant radiometric differences were found for the same type of forest cover in the three channel 3 images, even for the same geographical location. This can be seen in table 4 which shows the variation of grey levels for ten different sites in the AVHRR channel 3 images, in the same respective locations and for the three dates analysed. In each image ten samples of the class forest were used, where each sample consisted of four to six pixels. These differences result from the sensor measurement of a combined signal of emittance (function of surface temperature) and reflectance (function of solar illumination) from any surface cover at day-time. This effect brings a major limitation in the comparison of channel 3 images since no actual fixed radiometric reference is maintained for terrestrial ground covers.

The radiometric differences were reduced after the histograms of these images were compared and a different slice threshold was selected for each image. This procedure was necessary because different classification patterns of forest and nonforest boundaries resulted depending on the limit of the grey level used in the slicing process. The lower threshold of grey level adopted for the forest class in each image was the lowest level found for the ten samples of the corresponding image; in the three images this limit always corresponded to that of sample 5. Therefore, for each image, pixels with grey level below (or higher temperature) that of the corresponding sample 5 were considered as non-forest, deforestation or savannas. The three individual images after the classification process are presented in figure 3, with the magenta colour depicting all non-forest covers; the two resulting difference images are shown in figure 4 . This last figure presents the difference images and contains the following classes: (a) green colour for the remaining natural forest cover; $(b)$ dark blue for non-forest on both dates, comprising old deforestation and savannas; (c) red for new deforestation detected between September 1989 and September 1990 (figure 4(a)), and between July 1990 and September 1990 (figure 4(b)); (d) light blue for other vegetation, presumably secondary vegetation and; $(e)$ white for clouds. The essential information in the difference images is therefore shown by the pixels in green and red, with the red pixels indicating the forest that was eliminated between the two dates of the original pair of images used to obtain the respective difference image.

Figure 2. Channel 3 AVHRR images: (a) 17 September 1989; (b) 30 July 1990; (c) 15 September 1990. 


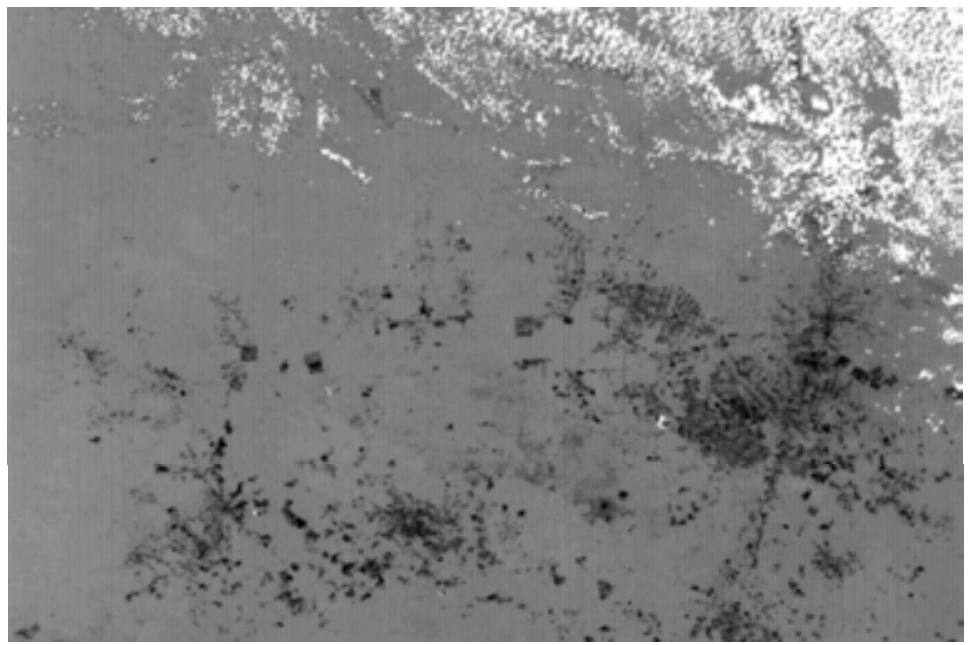

(a)

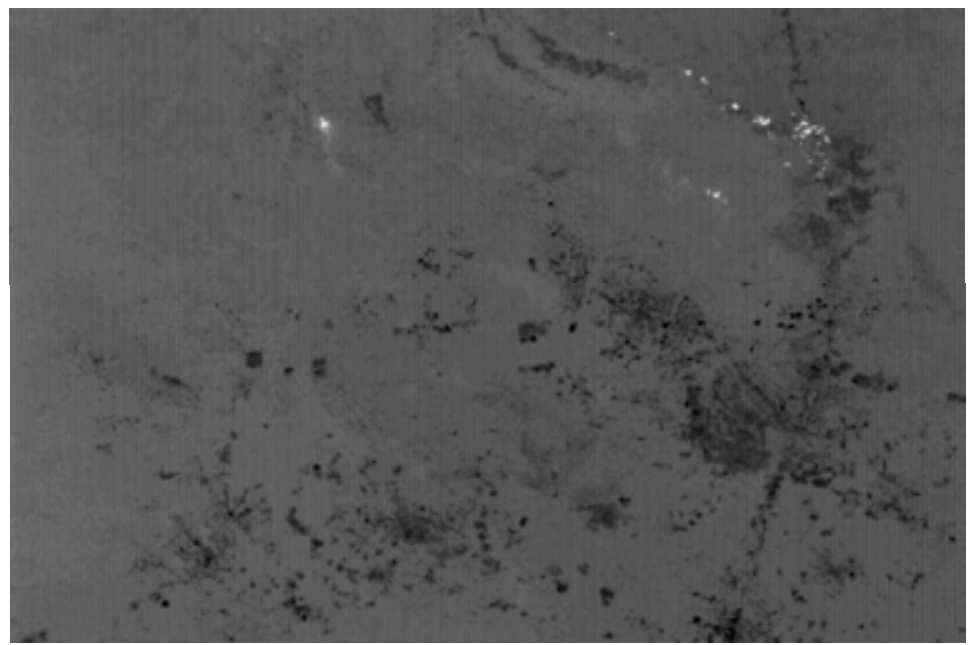

(b)

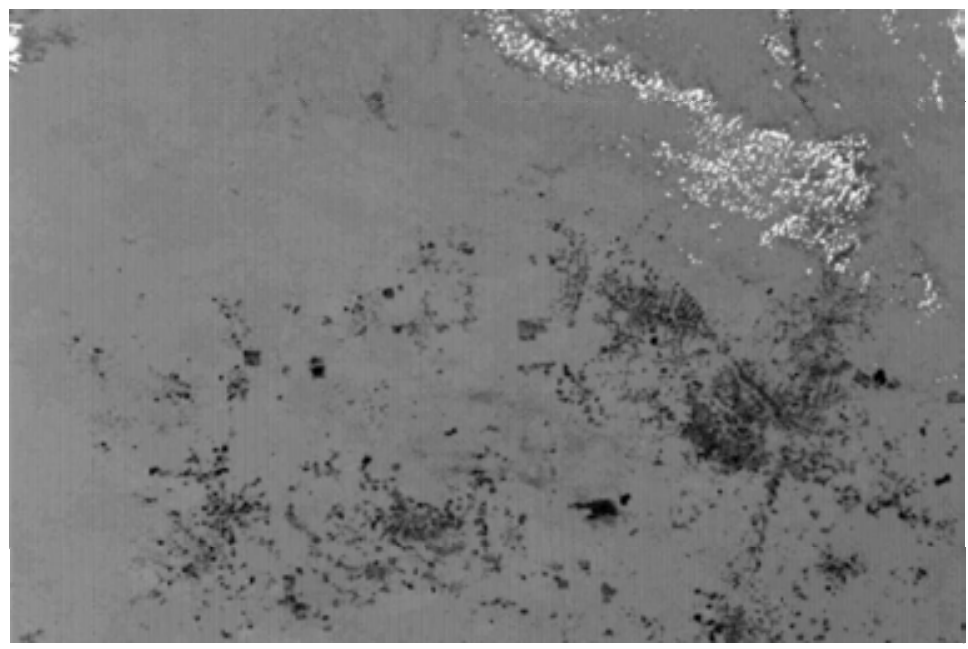

(c) 
Table 4. AVHRR channel 3 radiometric variation for forests in three images.

\begin{tabular}{lccc}
\hline & \multicolumn{2}{c}{ Radiometric digital counts in AVHRR images } \\
\cline { 2 - 4 } $\begin{array}{l}\text { Number of the } \\
\text { forest sample }\end{array}$ & $\begin{array}{c}\text { Image of } \\
\text { September 1989 }\end{array}$ & $\begin{array}{c}\text { Image of } \\
\text { July 1990 }\end{array}$ & $\begin{array}{c}\text { Image of } \\
\text { September 1990 }\end{array}$ \\
\hline 1 & 121 & 147 & 136 \\
2 & 120 & 154 & 131 \\
3 & 118 & 136 & 116 \\
4 & 132 & 152 & 141 \\
5 & 111 & 128 & 113 \\
6 & 128 & 142 & 131 \\
7 & 136 & 146 & 142 \\
8 & 122 & 131 & 122 \\
9 & 124 & 138 & 127 \\
10 & 120 & 138 & 134 \\
Mean & $123 \cdot 2$ & $141 \cdot 2$ & $129 \cdot 3$ \\
Std.Deviation & $7 \cdot 2$ & $8 \cdot 6$ & $9 \cdot 8$ \\
\hline
\end{tabular}

\subsection{Validation of classifications}

The validation of the deforestations shown in the AVHRR difference images was based on their identification in the TM deforestation maps prepared by INPE (Alves et al. 1992) on a yearly basis. The deforestation sites in the five sub-areas of study indicated in the AVHRR difference images of July 1990-September 1990 (JS) and September 1989-September 1990 (SS) numbered 764 and 807, respectively. In the TM reference map of new deforestation for 1989-90, the number of deforestation polygons for the five sub-areas was 882 ; individually, the sub-areas of figure 1 had the following numbers of polygons (area ID/number of polygons): 274/265; 297/170; 298/110; 319/135; and 320/202. The number of TM deforestation polygons compared was 221 for the JS image and 216 for the SS image, about a fourth of the total; the small difference of five polygons in the two cases resulted from a limitation in the processing system.

The comparative results are presented in tables 5 and 6. For the SS image 106 deforestation sites were properly identified in the AVHRR data, or $49 \cdot 1$ per cent; in the JS image, 125 sites, or 56.6 per cent of the total cases, were correctly located. The incorrect AVHRR classification of deforestation for 1990 in relation to the TM data appears to be related to the size of the deforestation sites, or polygons, considered. As observed in the TM images, deforestation polygons with less than about $3.1 \mathrm{~km}^{2}$ were usually not detected in the AVHRR difference image; this feature is probably related to the AVHRR resolution which varied from a nominal value of $\sim 1.2 \mathrm{~km}^{2}$ at nadir to $\sim 2 \mathrm{~km}^{2}$ depending on the off-nadir pixel position in the AVHRR images used. Under such conditions, a deforestation polygon with up to $4 \mathrm{~km}^{2}$ could be split among four or more neighboring pixels and occupy just a fraction of each of these pixels, without therefore producing a strong enough signal in the pixel to discriminate it from the surrounding ground covers.

Figure 3. Channel 3 AVHRR images with classification patterns: (a) 17 September 1989;

(b) 30 July 1990; (c) 15 September 1990. 


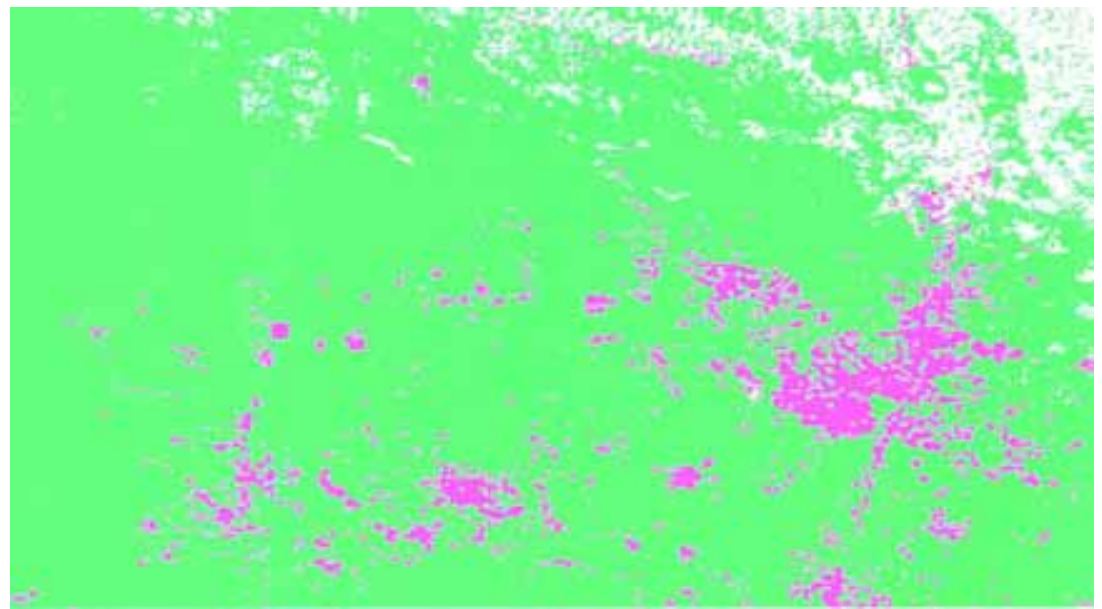

(a)

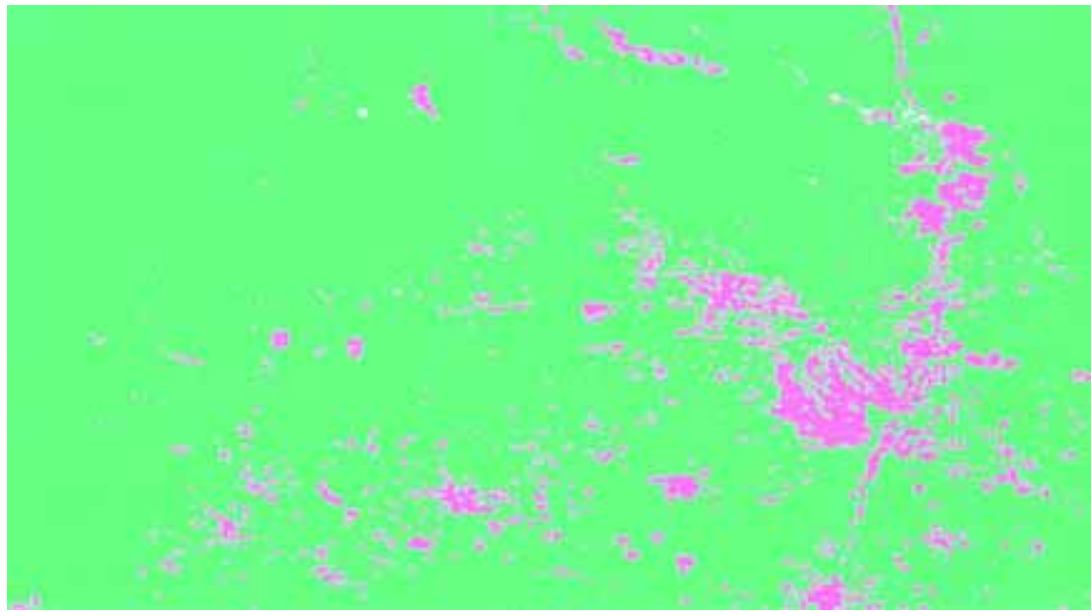

(b)

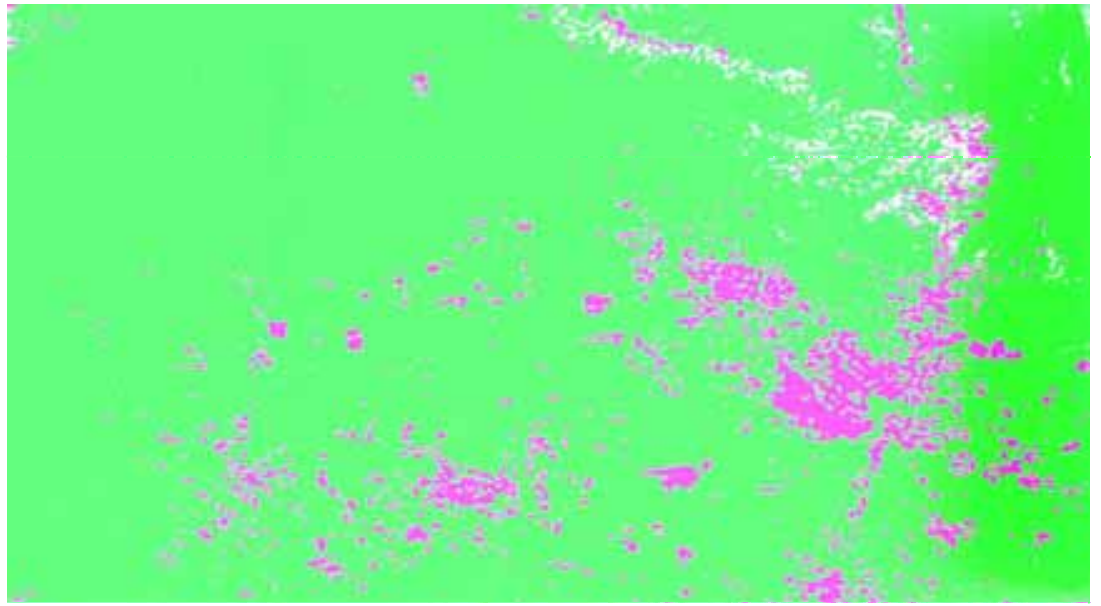

(c) 


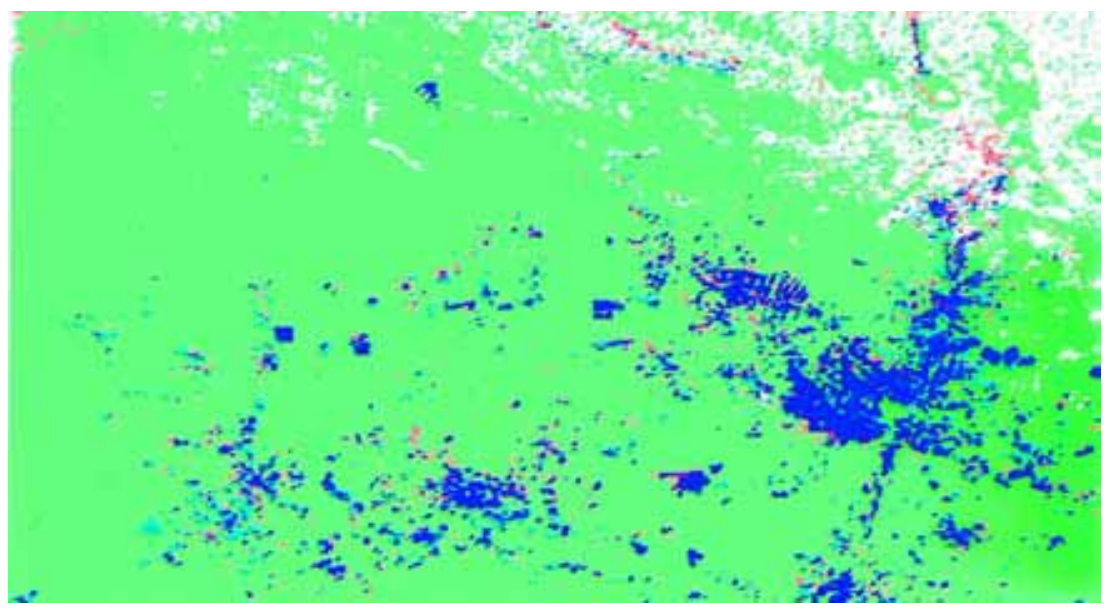

(a)

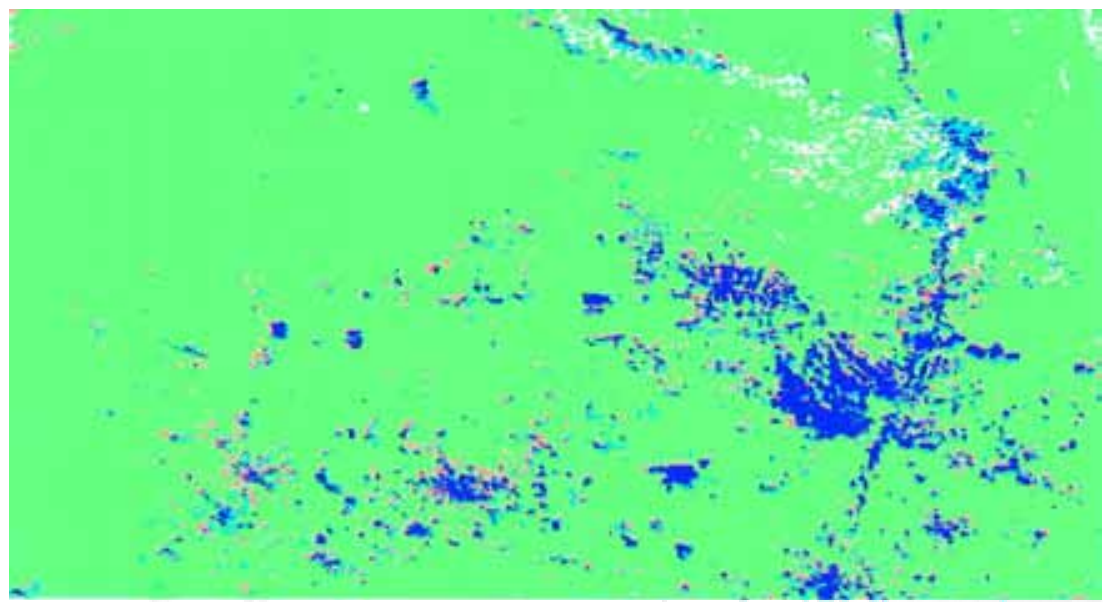

(b)

Figure 4. AVHRR resulting 'difference images': (a) September 1989-September 1990; (b) July 1990-September 1990.

The twenty-three and twenty-two TM deforestation polygons, when plotted on the AVHRR corresponding difference image, were located in areas classified as secondary/other vegetation-see tables 5 and 6 . Additionally, these tables show respectively that eleven and six TM deforestation polygons were identified by the AVHRR as old deforestation or savannas. In both cases the centers of these TM deforestation polygons were located very close to the boundaries of the AVHRR classification of natural forest with secondary forest or with old deforestation. These misclassifications probably resulted from two reasons: small TM deforestation polygons not detected by the AVHRR resolution, and minor distortions between the AVHRR images in each of the pairs used which could not be corrected by the navigation algorithm developed in this work. 
Table 5. Results of the AVHRR 'difference image' between September 1989 and September 1990.

\begin{tabular}{lcccccc}
\hline & & \multicolumn{5}{c}{ Classification in the AVHRR 'difference image' } \\
\cline { 3 - 7 } $\begin{array}{l}\text { TM } \\
\text { charts }\end{array}$ & $\begin{array}{c}\text { Number of } \\
\text { deforestation } \\
\text { polygons }\end{array}$ & $\begin{array}{c}\text { New } \\
\text { deforest. }\end{array}$ & $\begin{array}{c}\text { Secondary } \\
\text { vegetation }\end{array}$ & Forest & Others & Clouds \\
\hline 274 & 40 & 25 & 02 & 10 & 03 & - \\
297 & 40 & 17 & 03 & 19 & 01 & - \\
298 & 43 & 17 & 09 & 13 & 04 & - \\
319 & 40 & 20 & 05 & 13 & 02 & - \\
320 & 53 & 27 & 04 & 21 & 01 & - \\
Total & 216 & 106 & 23 & 76 & 11 & - \\
$\%$ & 100 & $\mathbf{4 9 \cdot 1}$ & $10 \cdot 6$ & $35 \cdot 2$ & $5 \cdot 1$ & - \\
\hline
\end{tabular}

Table 6. Results of the AVHRR 'difference image' between July 1990 and September 1990.

\begin{tabular}{lcccccc}
\hline & & \multicolumn{5}{c}{ Classes in the AVHRR 'difference image' } \\
\cline { 3 - 7 } $\begin{array}{l}\text { TM } \\
\text { charts }\end{array}$ & $\begin{array}{c}\text { Number of } \\
\text { deforest. } \\
\text { polygons }\end{array}$ & $\begin{array}{c}\text { New } \\
\text { deforest. }\end{array}$ & $\begin{array}{c}\text { Secondary } \\
\text { vegetation }\end{array}$ & Forest & Others & Clouds \\
\hline 274 & 45 & 33 & 01 & 10 & 01 & - \\
297 & 40 & 19 & 06 & 14 & 01 & - \\
298 & 44 & 24 & 06 & 14 & - & - \\
319 & 40 & 25 & 02 & 11 & 02 & - \\
320 & 52 & 24 & 07 & 19 & 02 & - \\
Total & 221 & 125 & 22 & 68 & 06 & - \\
$\%$ & 100 & $56 \cdot 6$ & $9 \cdot 9$ & $30 \cdot 8$ & $2 \cdot 7$ & - \\
\hline
\end{tabular}

When the condition of more than $3 \cdot 1 \mathrm{~km}^{2}$ per TM deforestation polygon was used, the JS AVHRR difference image also showed a better detection result than the SS difference. Table 7 indicates that in the former 90 per cent of the polygons were correctly detected while in the latter this figure was 82 per cent. Deforestation polygons larger than $3.1 \mathrm{~km}^{2}$ not detected by AVHRR were examined in the TM

Table 7. Summary of the TM deforestation polygons larger than $3 \cdot 1 \mathrm{~km}^{2}$ correctly classified in the AVHRR.

\begin{tabular}{lccc}
\hline & & \multicolumn{2}{c}{ Scores, AVHRR 'difference image' } \\
\cline { 3 - 4 } $\begin{array}{l}\text { TM reference } \\
\text { chart }\end{array}$ & $\begin{array}{c}\text { Number of TM } \\
\text { polygons/chart }\end{array}$ & $\begin{array}{c}\text { September 1989- } \\
\text { September 1990 }\end{array}$ & $\begin{array}{c}\text { July 1990- } \\
\text { September 1990 }\end{array}$ \\
\hline 274 & 9 & 8 & 9 \\
297 & 7 & 6 & 7 \\
298 & 7 & 6 & 7 \\
319 & 10 & 10 & 10 \\
320 & 17 & 11 & 12 \\
Total & 50 & 41 & 45 \\
$\%$ & 100 & 82 & 90 \\
\hline
\end{tabular}


Table 8. Total amount of TM deforestation polygons in 1990 with the percentages of false alarms in the AVHRR 'difference images'.

\begin{tabular}{|c|c|c|c|c|c|c|}
\hline \multirow{3}{*}{$\begin{array}{l}\text { TM } \\
\text { sampling } \\
\text { areas }\end{array}$} & \multicolumn{6}{|c|}{ AVHRR 'difference images' } \\
\hline & \multicolumn{3}{|c|}{$\begin{array}{l}\text { September } 1989- \\
\text { September } 1990\end{array}$} & \multicolumn{3}{|c|}{$\begin{array}{c}\text { July } 1990- \\
\text { September } 1990\end{array}$} \\
\hline & $\begin{array}{l}\text { Total } \\
\text { alarms }\end{array}$ & $\begin{array}{l}\text { False } \\
\text { alarms }\end{array}$ & $\%$ & $\begin{array}{l}\text { Total } \\
\text { alarms }\end{array}$ & $\begin{array}{l}\text { False } \\
\text { alarms }\end{array}$ & $\%$ \\
\hline 274 & 222 & 58 & $26 \cdot 1$ & 230 & 53 & $23 \cdot 0$ \\
\hline 297 & 94 & 13 & $13 \cdot 8$ & 92 & 24 & $25 \cdot 5$ \\
\hline 298 & 134 & 36 & $26 \cdot 8$ & 105 & 34 & $32 \cdot 4$ \\
\hline 319 & 139 & 55 & $39 \cdot 5$ & 135 & 47 & $34 \cdot 8$ \\
\hline 320 & 218 & 99 & $45 \cdot 4$ & 202 & 90 & $44 \cdot 5$ \\
\hline Total & 807 & \multicolumn{2}{|c|}{261} & 764 & \multicolumn{2}{|c|}{248} \\
\hline$\%$ & 100 & \multicolumn{2}{|c|}{$32 \cdot 3$} & 100 & \multicolumn{2}{|c|}{$32 \cdot 4$} \\
\hline
\end{tabular}

images and were typically characterized by selective cutting (Uhl and Vieira 1989), where only some of the trees are removed. In the TM imagery, those loggings produce only minor and barely noticeable differences in texture and contrast in relation to the surrounding forest (Lefebvre and Stone 1994). Therefore, with its coarse resolution, AVHRR mostly enabled detection of the major changes in the vegetation cover.

Table 8 shows the number of deforestation sites indicated by the AVHRR difference images that could not be found in the TM data (i.e., false alarms). From the 807 and 764 deforestation sites in the difference images of SS and JS, about 10 per cent occurred in areas of savannas or where the forest had been long removed. If areas of this ecosystem are not considered, the percentage of false alarms is reduced to about 22 per cent. Possible reasons for the false alarms include the following, either independently or combined: $(a)$ changes in the vegetation cover, also in savanna areas; (b) large radiometric variations for a same area in different images; $(c)$ minor differences in the registration of images of different dates; and $(d)$ confusion in the digital classification caused by mixed pixels (Cross 1991) in the contact border of forest-deforestation and forest-savanna areas. And lastly, of the $35 \mathrm{TM}$ images used to prepare the AIS thematic map used to verify the AVHRR detection, only three of them actually referred to a date after the last AVHRR image on 15 September 1990 (see table 2); therefore it is also possible that some deforestation occurred after the acquisition dates of these TM scenes, being detected only by the AVHRR, without possibility of validation.

\section{Conclusion}

The new methodology developed and tested showed that the low resolution AVHRR sensor may also be used directly to detect significant changes in the vegetation cover of a tropical forest. Coupled to its fast and low cost product output capability, a significant amount of new deforestation may be detected on real-time instead of when the burning takes place or months-to-years later when high resolution imagery is analysed. 
Although limitations exist in the novel methodology, mainly of radiometric and registration nature, the use of a relatively simple semi-automatic system for deforestation detection has been demonstrated within acceptable accuracy expectations.

\section{Acknowledgments}

The authors are thankful to A. E. Fernandes for the development of the software used in the AVHRR processing and to E. M. Kalil Mello for the access to the TM imagery and maps of the INPE Amazon Project. This work was partially supported by grant \#90/2950-2 from Fundação de Amparo a Pesquisa de São Paulo_FAPESP.

\section{References}

Alves, D. S., Meira Filho, L. G., D’Alge, J. C. L., Mello, E. K. De, Moreira, J. C. and Medeiros, J. S. De, 1992, The Amazonia Information System. Proceedings of the International Archives of Photogrammetry and Remote Sensing (Washington: ISPRS), pp. 259-266.

Amaral, S., 1992 a, Deforestation estimates in AVHRR/NOAA and TM/LANDSAT images for a region in central Brazil. Proceedings of the International Archives of Photogrammetry and Remote Sensing, (Washington: ISPRS), pp. 764-767.

Amaral, S., 1992 b, Imagens do sensor AVHRR/NOAA na detecção e avaliação de desmatamentos na floresta Amazônica-relações com dados do sistema TM/Landsat. MSc thesis. Instituto Nacional de Pesquisas Espaciais, São José dos Campos. (INPE5501-DI/516), in Portuguese.

CRoss, A., 1991, Tropical forest monitoring using AVHRR: towards an automated system for change detection. Geneve, UNEP/GRID. Final report to the Commission of the European Communities.

Di Maio Mantovani, A. C., 1994, Detecção de desmatamentos na floresta amazônica através de imagens AVHRR/NOAA e do sistema de informações geográficas SGI: metodologia e teste de um sistema potencial de alerta. MSc thesis. Instituto Nacional de Pesquisas Espaciais, São José dos Campos. (INPE-5580-TDI/543), (in portuguese).

DSG, 1981-3, Diretoria de Serviço Geográfico de Exército. Cartas Topográficas MIR 297, 298, 319 and 320 1:250,000-Corte sistemático.

Ehlers, M., Edwards, G. and BÉDARD, Y., 1989, Integration of remote sensing with geographic information system: a necessary evolution. Photogrammetric Engineering and Remote Sensing. 55, 1619-1627.

Fearnside, P. M., 1990, The rate and extent of deforestation in Brazilian Amazonia. Environmental Conservation, 17, 213-225.

Fernandes, A. E., Setzer, A. W. and Pereira, M. C., 1993, DesF LO Program, unpublished. São José dos Campos, INPE.

IBGE, 1982, Instituto Brasileiro de Geografia e Estatística. Carta Topográfica MIR 274 1:250 000-Corte sistemático.

InPE, 1986, Instituto Nacional de Pesquisas Espacias. Departamento de Processamento de Imagens. Manual do usuário do SITIM (São José dos Campos: INPE).

INPE, 1989, Instituto Nacional de Pesquisas Espacias Departamento de Processamento de Imagens (INPE. DPI). Manual do usuário do SIG (São José dos Campos: INPE).

INPE, 1992, Instituto Nacional de Pesquisas Espacias. Deforestation in Brazilian Amazonia. Folheto (São José dos Campos: INPE).

Justice, C. O., Townshend, J. R. G., Holben, B. N. and Tucker, C. J., 1985, Analysis of the phenology of global vegetation using meteorological satellite data. International Journal of Remote Sensing, 6, 1271-1318.

Kaufman, Y. J. and Remer, L. A., 1994, Detection of forests using mid-IR reflectance: an application for aerosol studies. I.E.E.E. Transactions on Geoscience and Remote Sensing, 32, 672-683.

Kidwell, K. B., 1993, NOAA polar orbiter data (Tiros-N, NOAA-6, NOAA-7, NOAA-8, NOAA-9, NOAA-10, NOAA-11 and NOAA-12) Users guide (Washington, D.C., NOAA/ NESDIS ). 
Lefebvre, P. A. and Stone, T. A., 1994, Monitoring selective logging in Eastern Brazilian Amazonia using multi-temporal Landsat thematic mapper imagery. Proceedings of the International Society of Photogrammetry and Remote Sensing Commission VII Symposium, Rio Janeiro, Brazil, Vol 30, (São José dos Campos: INPE) part A, pp. 288-291.

Malingreau, J. P. and Tucker, C. J., 1988, Large scale deforestation in the southeastern Amazon basin of Brazil. Ambio, 17, 49-55.

Martini, P. R., 1993, Panamazonia Project to monitor tropical forest in South America. Proceedings of the VI Latin American Remote Sensing Symposium, Cartagena, Colombia, 3-8 October 1993 (São José dos Campos: INPE).

Projeto R ADAM-Brasil, 1980, Folha SC-21 Juruena: geologia, geomorfologia, solos, vegetação, uso potencial da terra (Rio de Janeiro: DNPM) (Levantamento de Recursos Naturais, 20).

Skole, D. L. and Tucker, C. J., 1993, Tropical deforestation and habitat fragmentation in the Amazon: satellite data from 1978 to 1988. Science, 260, 1905-1909.

UhL, C. and Vieira, I. C. G., 1989. Ecological impacts of selective logging in the Brazilian Amazon: a case study for the Paragominas region of the state of Pará. Biotropica, 21, 98-106. 